\title{
Poverty, Female Labour Force Participation, and Cottage Industry: A Case Study of Cloth Embroidery in Rural Multan
}

\author{
Toseef AzID, MuHammad Aslam, and MuHAmmad OMEr CHAUdhary
}

It is a well-known fact that cottage industries can play a significant role in the development of an economy like Pakistan. As it is observed that this industry is not required too much financing, imported and highly sophisticated technology. So the problems like deficit in public finance and balance of payments is not related with the growth and development of these industries. Simultaneously, high degree of female labour force participation in this sector has also been proved in the number of studies. Which seems to be helpful in the process of reduction of poverty especially in the rural areas.

The Southern Punjab especially its rural areas are comparatively less prosperous than the other parts of Punjab. A number of female workers can be seen in the rural areas of Southern Punjab. The concentration of these workers is in few traditional areas and is characterised by the low technology and low production levels. These areas are typically those, which require skills that are basically the extension of household skills or which reflect a specific educational and employment experience of women. It has also been observed that women's income of the rural areas of Southern Punjab are more likely than their male partners to go towards meeting their family's basic needs. These women spent most of their business income on the households, food, clothing and education of their children rather than reinvesting it in their business.

As can be seen most females are involved in the business of cloth embroidery. The entrepreneurs of the urban areas are exploiting them so that the returns remain meagre. The production of these workers have many folds values in the metropolitan areas and also have high demand in the Central and Northern areas of the Country. The consumer of these products belongs to the affluent class.

Toseef Azid is Professor of Economics, Bahauddin Zakariya University, Multan. Muhammad Aslam is Director Development, Commissioner Office, Bahawalpur. Muhammad Omer Chaudhary is Lecturer, Department of Economics, Bahauddin Zakariya University, Multan. 
Unfortunately, such income has not been instrumental in reducing the level of their poverty. It is therefore, of crucial importance to find ways to assist these female workers to increase their productivity and thereby their income.

Keeping this in view a study is conducted in the rural areas of Multan. This study is based on the primary data. Section I explains the background of the subject. Section II discusses the economic and social status of female workers and also measures their poverty level. Section III gives some statistical estimation. At the end some policy measures are suggested.

\section{SECTION I}

A number of attempts can be seen in the literature related to the economic theory of the household e.g. Becker (1965) and Gronau (1977) are the pioneer in the field and discussed time allocation behaviour of households. However, a vast variety of literature is available which is based on the empirical studies especially for the developed countries. Among them the most important are surveys carried by Killingsworth and Heckman (1986) and Heckman and Macurdy (1980).

Cain and Watts (1973) surveyed the literature about the measures of labour supply and discussed the basic concept of the subject in detail. A special case of the family utility function considered in detail by Cohen, et al. (1970) and by Ashenfelter and Heckman (1974). Among others Mauser and Brown (1979, 1980) and McElory and Horney (1981) developed the family economics. Becker $(1974,1981)$ gave the importance of the marital status in the models of household labour supply. Mincer (1962) and Mitchell (1980) discussed the added worker effect and discouraged worker effect in the context of family economics.

Market and non-market activities are discussed by Becker (1965) in detail and further it is developed by Gronau (1973, 1977, 1973). Cogan (1980, 1980a, 1981) emphasised the effect of job costs and labour supply in model of family economics.

Killingsworth and Heckman (1986) surveyed the empirical literature and divided them as first and second-generation studies. First generation studies are relying on ordinary least square estimation e.g. Cain (1966) and Cain and Watts (1973). A distinguished feature of second-generation models of labour supply is the explicit treatment of utility function and unobservable variables, e.g. see Amemiya (1973); McDonalds and Muffit (1980); Goldbager (1981); Greene (1981) and most important is the work of Heckman (1974, 1976, 1979, 1980). Killingsworth (1983) has distinguished eight estimation procedures that attempts in attractive ways to deal with missing wage data for non workers,

In the recent literature Altug and Miller (1998); Cogatay and Ozler (1995); Klaauv (1996) discussed the female labour supply for the developed economy. 
Khandker (1988); Hill (1982); Fong (1975) and Yusuf and Burgis (19979) discussed the female labour force participation in the developing countries.

Whereas particular to Pakistan Sultana, et al. (1994); Afzal and Nasir (1987); Hakim and Aziz (1998); Shah (1986, 1986a, 1975); Kazi and Raza (1991); Chaudhry and Khan (1987) and Hamid (1991) discussed the different aspects of the female participation in the labour force

\section{SECTION II}

Multan is famous for its clothes embroidery. This business is three tiers, i.e. final supplier, middleman, and the workers. Most of the workers are female in the rural Multan in the cloth embroidery. It is interesting to note that all the suppliers are the shopkeepers and they have their own stores in Multan city or in the shopping centres of cantonment. Approximately 60-70 entrepreneurs run their business successfully in Multan. The main objective of the study is to analyse the economic behaviour of the female workers involved in the business of embroidery. The data of these workers are collected from the shopkeepers and from the middleman. An effort was made to approach all the workers but it was not possible due to certain social constraints. However, a quite enough number was approached and on the basis of that a survey was conducted. It was astonished to know that it was for the first time that such a survey was conducted.

\subsection{Profile of the Woman Worker}

In this sub section a profile of the typical woman involved in the embroidery is given.

Majority of the workers informed that they started their work as a hobby. Presently, they tried to increase their family income, because the economic condition of their family is not good and they wanted to fulfil the basic requirement of their family especially the requirements of the younger members of family.

Table 1 summaries the reasons.

Table 1

Reasons to Participate in the Labour Force

\begin{tabular}{lc}
\hline Reasons & Percentage \\
\hline Economic & 70 \\
Hobby & 10 \\
Because of Friends & 15 \\
Tradition & 05 \\
\hline Source: Data collected by the authors in their survey.
\end{tabular}

Source: Data collected by the authors in their survey. 
Table 1 explains the reasons of participation in the labour force and as mentioned above majority of the labour force involved in the business due to their poor economic conditions. Female participation of the rural households in the market activities is an important characteristic of Pakistan's economy. However, both male and female contribute their labour input in the income of household but males play a dominant role because of their access to technologies, resources, output and influence of decision process [Khandkar (1987)]. But one cannot ignore the market activities of women. In reality their income is a supplement to the family and mainly it is consumed as the complement of the consumption of the family.

In the production of cloth embroidery cloth they only supply the labour. Whereas cloth and other inputs are supplied by the traders and the middlemen

Table 2 shows that how much time they allocate to market and non-market activities.

Table 2

Share of Market and Non-Market Activities

\begin{tabular}{lcc}
\hline & Market & Non-Market \\
\hline Less than 10 Percent & 8 hours/day & $2-4$ hours/day \\
2 Percent & $6-7$ hours/day & $4-6$ hours/day \\
40 Percent & $4-5$ hours/day & 6 hours/day \\
30 Percent & 3 hours/day & Approx 8 hr/day \\
\hline
\end{tabular}

Source: Data collected by the authors.

The majority of the workers allocate their time to the more non-economic activities than to market activities. In return they are not able to earn more. Kottis (1990) and others have argued that the decision of woman to participate in the labour force can be considered as the output of the decision making process of the household to which she belongs. How to allocate their time between work and home, working the market and leisure is based on the combined household utility. It is also assumed that time saving devices such as microwave oven, washing machine etc has positive effect on the female labour force participation. As it is observed from Table 2 that majority of female workers those involved in the cloth embroidery are given more time to non-market activities which confirms the hypothesis of nonavailability of time saving devices. It is well known factor that in the rural areas of Pakistan these devices are not commonly used especially in the poor households.

\subsection{Demographic Profile of the Workers}

Table 3 depicts the demographic profile of the female workers in the business of embroidery. Most of the workers are not educated. Majority of them are falling in the age group of 16-30. This table also shows the social behaviour of Pakistan's society. Because in most of the poor families the women are not attending the school 
Table 3

\begin{tabular}{lc}
\multicolumn{2}{c}{ Demographic Profile of the Workers } \\
\hline Age & $20 \%$ \\
16-20 Years & $30 \%$ \\
$20-25$ Years & $28 \%$ \\
$25-30$ Years & $15 \%$ \\
30-40 Years & $07 \%$ \\
40-60 Years & \\
Education & $42 \%$ \\
No Schooling & $37 \%$ \\
Primary & $14 \%$ \\
Middle & $07 \%$ \\
Matric and Above & \\
Family Income (Per Capita) & $53 \%$ \\
Less Than 500 & $22 \%$ \\
500-600 & $20 \%$ \\
600-700 & $5 \%$ \\
Above 700 & \\
Work Experience & $22 \%$ \\
Less than 5 Years & $48 \%$ \\
5-10 Years & $18 \%$ \\
10-15 Years & $12 \%$ \\
Above 15 years & \\
\hline Source: Calculated by the authors on the basis of Survey Results.
\end{tabular}

and the prevailing customs are also not in the favour of female education. May be this is the one of the reason that 79 percent female workers in our sample have obtained only primary education. Only 7 percent are matriculate or above. It is observed from the age segment that majority of women supplying labour force are between 16-30 years of age. It may be due to the family structure of rural as well as the urban areas of Pakistan. The growth of the family increases the responsibilities of the housewives/mothers so this phenomenon does not permit most of the women to supply labour for market activities. It has also been observed that in the rural areas of Pakistan after the middle age the women are not in the good health so due to this they are not in position to perform the work of embroidery. It may be one of the causes of low labour supply in this cottage industry after the age of 30. In the age segment (30-60 years) only 22 percent are supplying their labour for embroidery. Most of the workers supplying labour in this cottage industry are not well educated. Here may be psychological phenomenon is working that more educated women are not considering it as normal good. Here substitution effect says work less in embroidery because they can earn more from the alternative sources e.g. home tuition or jobs in the formal and informal sectors etc. 
53 percent of the worker's families are living below poverty line (the National poverty line is used for this measure). Only 5 percent of worker's families are having per capita income more than Rs 700. Work experience gives another dimension of the analysis. It is astonished to know that workers having experience more than 15 years are only 12 percent. May be one can conclude that most of the workers are not able to work for the longer period, due to cultural, social and other reasons. The results also suggest the similar reasons as we have been discussed for the age of the workers.

Table 4 depicts the per capita income (excluding the worker's Income) of the worker's family. It shows that with the earning of these workers the poverty level of their families reduces. 77 percent are falling under poverty line instead of 53 percent whereas the last segment is showing the same 5 percent. It is remarkable to note that how their earnings are contributing in the welfare of the household. This implies that labour supply function of the family member depends not only on his or her but also on the labour and non-labour income of the family.

Table 4

\begin{tabular}{lc} 
Monthly Per Capita Income of the Families, Excluding the Worker's Income \\
\hline Less than 500 & $77 \%$ \\
500 to 600 & $12 \%$ \\
600 to 700 & $06 \%$ \\
Above 700 & $5 \%$ \\
\hline
\end{tabular}

Source: Calculated by the authors on the basis of results of Survey.

It is argued in the different studies that number of children is also played a significant role in the participation of female in work, especially children under 5 years of age. It implies that looking after a child and earning of mother are substitute of each other.

Approximately 40 percent of the female workers are having children less than five years of age, and they allocated less time to work and more to home. Some social factors like family system (nucleus or joint), Purdah (veil) and the distance from the market are also have their own impact on the female labour force participation. (Their statistical impact will be discussed in Section III.) However, approximately 93 percent of total workers in our sample are Purdah observing, whereas more than 60 percent are living in a joint family system. Most of them are complaining about the distance to a town or market centre. An increase in the household distance to the market centre means a higher transaction cost for market purchased goods and also higher for employment. 
These may imply a decrease in the probability of women's participation in the labour force.

Table 5 describes the areas in which women working in the industry of embroidery are facing obstacles. Due to imperfection in the market they have less information and limited bargaining power. Social setup is a main obstacle in their mobility. Majority was complaining about the behaviour of the middleman. However, most of them seemed to be helpless and were not optimistic about their own future. It is observed from the survey that these workers are very much neglected. They are neither being supported by the government nor by the society.

Table 5

\section{Major Obstacles Observed by the Female Workers}

\begin{tabular}{lc}
\hline Limited Bargaining Power & $62 \%$ \\
Limited Mobility & $79 \%$ \\
Male Dominated Market & $67 \%$ \\
No Protection from Government & $83 \%$ \\
Exploitation from the Producer & $85 \%$ \\
Distance from the Market & $92 \%$ \\
Middle Man & $94 \%$ \\
Lack of Information & $66 \%$ \\
Low Wage Rate & $100 \%$ \\
\hline Source: Calculated by the authors on the basis of results of their survey.
\end{tabular}

\section{SECTION III}

This section is based on some statistical estimation of the female supply of labour in the sector of embroidery in Multan. The results were obtained using the OLS (Ordinary Least Squares, for detail see Table 6).

Another motivation of this exercise is to test the hypothesis that a family in the rural society like Pakistan will send its female members to the labour market only if the family's income drops very low. ${ }^{1}$

The estimated coefficient of the poverty variable is strong and statistically significant. This shows that these workers play a great role in pulling the households out of poverty. The co-efficient of age-squared variable is insignificant suggesting a linear relationship between women's labour hours and age. However the sign of variable is negative. May be the older women are likely to spend time in unpaid domestic work (which have not been considered in this study). Workers living in far off areas work fewer hours than their other counterparts.

Without exceptions hours of female workers respond positively to their income. It is very interesting to note that number of male adults in the family has

\footnotetext{
${ }^{1}$ This is based on the Basu and Van ( 1998) 'luxury Axiom’.
} 
Table 6

Regression Estimation of Female Labour Supply

\begin{tabular}{|c|c|}
\hline Dependent Variable & $\begin{array}{l}\text { umber of Hours Supplied by the Female } \\
\text { Workers for Embroidery/Weak }\end{array}$ \\
\hline Constants: & $22.73 *(2.97)$ \\
\hline \multicolumn{2}{|l|}{ Independent Variables } \\
\hline \multicolumn{2}{|l|}{ Workers' Characteristics } \\
\hline Age & $29.49 *(6.82)$ \\
\hline Age $^{2}$ & $-3.27(1.03)$ \\
\hline Income & $39.46 *(7.93)$ \\
\hline Education A & $18.79 *(12.38)$ \\
\hline \multicolumn{2}{|l|}{ (1 if no Schooling, 0 otherwise) } \\
\hline Education B & $16.92 *(12.95)$ \\
\hline \multicolumn{2}{|l|}{ (1 if Primary, 0 otherwise) } \\
\hline Education C & $17.79 *(10.29)$ \\
\hline \multicolumn{2}{|l|}{ (1 if Middle, 0 otherwise) } \\
\hline Education D & $7.38(1.38)$ \\
\hline \multicolumn{2}{|l|}{ (1 if Matric and above, 0 otherwise) } \\
\hline \multicolumn{2}{|l|}{ Family Characteristics } \\
\hline Poverty Status & $48.31 *(7.69)$ \\
\hline \multicolumn{2}{|l|}{ (1 if below Poverty Line, 0 otherwise) } \\
\hline Number of Children (Below 5 Years) & 32.24 (1.03) \\
\hline Number of Male Adults & $-3.07 *(3.28)$ \\
\hline Gender of Household Head & 7.32 (1.63) \\
\hline \multicolumn{2}{|l|}{$(0=$ Male, 1 = Female $)$} \\
\hline Age of Household & 6.04 (1.39) \\
\hline Family Structure & $7.22 *(8.97)$ \\
\hline \multicolumn{2}{|l|}{ (1 if Joint, 0 otherwise) } \\
\hline Income of Household Head & $-8.98 *(6.35)$ \\
\hline \multicolumn{2}{|l|}{ Social Characteristics } \\
\hline Distance from the Market & $-2.73 *(2.94)$ \\
\hline Purdah & $3.68(1.29)$ \\
\hline \multicolumn{2}{|l|}{ (1 if Purdah Observing, 0 otherwise) } \\
\hline $\mathrm{R}^{2}=$ & 0.79 \\
\hline $\mathrm{F}=$ & $14.92 *$ \\
\hline
\end{tabular}


negative impact on the supply of labour hours. This phenomenon has both substitution and income effect. Traditionally in the rural areas the presence of male adults increases the family income and simultaneously their presence increases the unpaid domestic work of female members. This phenomenon can be explained as market determined prices are the wages of two categories of labour, adult male and adult female. An increase in the male wage rate will induce an increase in the supply of male's labour to market work. This will induce a corresponding decrease in the female's time allocation and participation in the market work, if male and female are substitute.

It is assumed that children under 5 years of age have a negative impact on the women labour supply. The estimated co-efficient of this variable is statistically insignificant. May be this effect is due to the family structure of the rural areas of Pakistan. This can be interpreted as if the children and mother are the substitute in production, it implies that the children can substitute the mother's time in work at home, thus releasing the work for market work and vice versa [see Khandkar (1987) for detail].

The co-efficient of Purdah is not statistically significant, because the nature of embroidery work is different from other fields and it is domestically based so in this respect the role of Purdah is negligible.

Furthermore, educational level, which is another individual characteristic, can be treated as an explanatory variable that may indicate productivity potential, both at home and in market production. Holding wages constant, an increase in the level of women's education can increase the probability of women's participation and time allocation in the market production if it increases the opportunity cost of staying at home. This may also imply an increase in women's time allocation in home production of education increases her home productivity. Thus, the ultimate effect of an increase in women's education level is indeterminate. Considering above, in this study four variables for education are used to estimate the effect of education on the women's supply of labour in this cottage industry. It is observed that up to middle standard (8 Years schooling) has a positive, strong and significant effect whereas after that it has insignificant effect. As it is expected, in the rural areas of Pakistan, with more education female have more opportunity or may be they spend more time on further education than work. Or it may be, as explained in the Section II becomes a low task job. Joint family system also has a positive impact of hours supplied.

\section{CONCLUSION}

This study purposes and applies a simple test of the hypothesis that there is a positive association between hours of female workers and household poverty. This is amended form of luxury axiom by Basu and Van (1998). It is based on this idea that in the traditional society the women are working for market activities, only if the income of the family falls to very low level. 
Determinants of women's work pattern in this cottage industry need to be identified for the public policy, programmes that seek to improve the well being of the rural population. There should be a solid programme from the government for the protection of these workers. This cottage industry is not well known but has enough shares in the business of Multan. Its production is not only consumed domestically but it has also share in the exports markets especially these products are exported to Far East and Europe. So this is the need of time to develop this sector in an organised way. Female labour force in this sector is observing a number of economic and social obstacles. An effort should be made to minimise these obstacles.

This problem has two dimensions, i.e. to improve the status of female workers and incentives should be provided to them. Other is to develop this sector on the priority basis for the economic and social development of rural sector and as well as for the enhancement of the foreign exchange.

Appendices

\section{APPENDIX A}

\section{History of Embroidery}

Multan is known for its cultural heritage. Embroidery is one of the famous cottage industries of this area. In the beginning this industry did not get the proper recognition as the market of embroided cloth was restricted to Metropolitan cities and some parts of Northern Areas. But now due to the interest of local entrepreneurs this cloth is being exported to Middle East, Indonesia, England, and Italy and USA.

\section{Process of Embroidery}

- Purchase of Raw material (Like cloth, thread etc.).

- Designing.

- Handing over of material to female workers.

- Preparation and Cross Check.

- Peco.

- Washing and Pressing.

\section{Process of Production}

If cost is Rs 120 than

- $\quad$ Cost of Middle man = Rs 10 .

- Cost of thread etc paid by middle man = Rs 15. (intermediate inputs are provided by the middle man).

- $\quad$ Payment to Workers = Rs 50 . 
- $\quad$ Other Expenditures (transportation etc.) = Rs 05 .

- $\quad$ Total Cost of final product $=$ Rs 80 .

- $\quad$ Cost of cloth = Rs 40 .

- $\quad$ Price in the market is Rs 180 to Rs 200.

(If a person gives 5 hour a day to one dupatta, than he or she will prepare it in 3 days it means they are spending 15 labour hours on one piece and getting Rs 3.5 against each labour hour.)

The data of workers were compiled from the producers of the embroidery cloth and from middleman. They are called agents. Most of the agents are female. Then applied the simple systematic random sampling on the basis of households. If there is more than one worker in an household than one is selected randomly through predetermined methodology. In most of the households more than one worker are observed.

\section{REFERENCES}

Afzal, M., and Z. M. Nasir (1987) Is Female Labour Force Participation Really Low and Declining in Pakistan? A Look at Alternative Data Set. The Pakistan Development Review 26:4, 699-707.

Altug, S., and R. A. Miller (1998) The Effect of Work Experience on Female Wages and Labour Supply. The Review of Economic Studies 65, 45-85.

Amemiya, T (1973) Regression when the Dependent Variable is Truncated Normal. Econometrica 41: 6, 997-1017.

Ashenfelter, O and J. Heckman (1974) The Estimation of Income and Substitution Effect in a Model of Family Labour Supply. Econometrica 42, 73-85

Basu, K., and P. H. Van (1998) The Economics of Child Labour. Geneva: International Labour Organisation.

Becker, G. S. (1965) Theory of the Allocation of Time. Economic Journal 76, 493517.

Becker, G. S. (1974) A Theory of Marriage. In Theodore W. Schultz (ed.) Economics of the Family. Chicago: University of Chicago Press. 293-344.

Becker, G. S. (1981) A Treatise on the Family. Cambridge, Mass: Harvard University Press.

Cain, G. C., and H. W. Watts (1973) Income Maintenance and Labour Supply. Chicago: Rand McNally.

Cain, G. G. (1966) Married Women in the Labour Force: An Economic Analysis. Chicago: University of Chicago Press.

Chaudhry, M. G., and Z. Khan (1996) Female Labour Force Participation Rate in Rural Pakistan: Some Fundamental Explanations and Policy Implications. The Pakistan Development Review 35: 4, 687-692. 
Cogan, J. F. (1980) Married Women’s Labour Supply: A Comparison of Alternative Estimation Procedure. In James P. Smith (ed.) Female Labour Supply: Theory and Estimation. Princeton, N. J.: Princeton University Press. 90-118.

Cogan, J. F. (1980a) Labour Supply with Fixed Cost of Labour Market Entry. In James P. Smith (ed.) Female Labour Supply: Theory and Estimation. Princeton, N. J.: Princeton University Press. 327-364.

Cogan, J. G. (1981) Fixed Cost and Labour Supply. Econometrica 49: 4, 997-1017.

Cogatay, N., and S. Ozler (1995) Feminisation of the Labour Force: The Effect of Long Term Development and Structural Adjustment. World Development 23:1, 1883-1894.

Cohen, M. S., A. R. Samual, and Robert I. Lerman (1970) A Micro Model of Labour Supply. Bureau of Labour Statistics, Washington, D. C. (Staff Paper No. 4.)

Fong (1975) Female Labour Force Participation in a Modernising Society. Malaya and Singapore 1921-1957 (Monograph); East West Population Institute, Hawaii.

Goldbagar, A. S. (1981) Linear Regression after Selection. Journal of Econometrics 15: 3, 357-366.

Greene, W. H. (1981) On the Asymptotic Bias of the OLS Estimation. Econometrica 49: 2, 505-513.

Gronau (1986) Home Production a Survey. Chapter 4. In Orley Ashenfelter and Richard Layrad (eds.) Handbook of Labour Economics Vol I. New York: Elsevier BV. 273-304.

Gronau, R. (1973) The Intrafamily Allocation of Time: The Value of the Housewives Time. American Economic Review 68, 634-52.

Gronau, R. (1977) Leisure, Home Production and Work: The Theory of Allocation of Time Revisited. Journal of Political Economy 85, 1099-1123.

Hakim, A., and A. Aziz (1998) Socio-cultural, Religious and Political Aspects of the Status of Women in Pakistan. The Pakistan Development Review 37:4, 727-746.

Hamid, S. (1991) Determinants of Supply of Women in the Labour Markets: A Micro Analysis. The Pakistan Development Review 30: 4, 755-766.

Heckman, J. J. (1974) Shadow Prices, Market Wages and Labour Supply. Econometrica 42, 679-94.

Heckman, J. J. (1976) Special Issue on Discrete Qualitative and Limited Dependent Variables. Annals of Economic and Social Measurement 5:5.

Heckman, J. J. (1979) Sample Selection Bias as a Specification Error. Econometrica. 47, 153-61.

Heckman, J. J. (1980) Sample Selection Bias as a Specification Error. In James P. Smith (ed.) Female Labour Supply. Princeton, N. J.: Princeton University Press. 206-248. 
Hill, M. N. (1982) Female Labour Force Participation in Developed and Developing Countries: Consideration of the Informal Sector. Review of Economics and Statistics 65, 459-68.

Kazi, S., and B. Raza (1991) Duality of Female Employment in Pakistan. The Pakistan Development Review 30:4, 733-743.

Khandker, S. R. (1987) Labour Market Participation of Married Women in Bangladesh. Review of Economics and Statistics.

Khandker, S. R. (1988) Determinants of Women's Time Allocation in Rural Bangladesh. Economic Development and Cultural Change 111-126.

Killingworth, M. R., and J. J. Heckman (1986) Female Labour Supply: A Survey Chapter 2. In Orley Ashenfelter and Richard Laynard (eds.) Handbook of Labour Economics Vol. 1. New York: Elsevier Science Publishers, BV. 103-204.

Killingworth, M. R. (1983) Labour Supply. New York: Cambridge University Press.

Klaauv, W. V. D. (1996) Female Labour Supply and Material Status Decision: A Life Cycle Model. Review of Economic Studies 63, 199-235.

Kottis, A. P. (1990) Shifts Over Time and Regional Variation in Women's Labour Force Participation Rate in a Developing Economy: The Case Study of Greece. Journal of Development Economics 33, 117-132.

Mauser, M. E., and M. Brown (1980) Marriage and the Household Decision-making: A Bargaining Analysis. International Economic Review 21:1, 31-44.

Mauser, M., and E. M. Brown (1979) Bargaining Analysis of Household Decision. In Cynthia B. Lloyd, Emily S. Andrews and Curtis L. Girlay (eds.) Women in Labour Market. New York: Columbia University Press. 3-26.

McDonald, and Muffit (1980) The Use of Tobit Analysis. Review of Economics and Statistics 67:2, 318-321.

McElary, M. B., and M. J. Horney (1981) Nash Bargain Household Decision: Towards Generalisation of the Theory of Demand. International Economic Review 22:2, 333-349.

Mincer, J. (1962) Labour Force Participation of Married Women: A Study of Labour Supply. In H. G. Lowis (ed.) Aspects of Labour Economics. Princeton, N. J.: Princeton University Press. 63-97.

Mitchell, O. S. (1980) Labour Force Activity of Married Women as a Response to Changing Jobless Rates. Monthly Labour Review 103:6, 73-112.

Shah, N. M. (1975) Work Participation of Currently Married Women in Pakistan: Influence of Socio-economic and Demographic Factors. The Pakistan Development Review 14:4, 482.

Shah, N. M. (1986) Change in Female's Role in Pakistan: Are the Volume and Pace Adequate? The Pakistan Development Review 25:3, 339-363.

Shah, N. M. (1986a) Pakistani Women: A Socio-economic and Demographic Profile. East West Population Institute. 
Sultana, N., H. Nazali, and S. J. Malik (1994) Determinants of Female Time Allocation in Selected Districts of Pakistan. The Pakistan Development Review 33:4, 1141-1153.

Yusuf, F., and D. K. Burgis (1979) Female Participation in the Labour Force of Selected Latin American Countries. The Pakistan Development Review 18:3, 215-229. 